\title{
Wychowanie patriotyczne w działalności oświatowej polskiej emigracji niepodległościowej na przykładzie Wielkiej Brytanii w latach 1945-1990
}

Każdy z nas uniósł za góry, za rzeki Cząstkę Ojczyzny w sercu W świat daleki, Ta czastka, bracia, to Język nasz stary To miłość kraju, cześć Ojców i wiary

(Maria Konopnicka)

\begin{abstract}
A b s trakt: Tematem artykułu jest emigracyjna działalność oświatowa wśród polskich uchodźców w Wielkiej Brytanii po 1945 r. Wychowanie patriotyczne stanowiło dla Polaków mieszkających poza granicami kraju jedno z najważniejszych zadań edukacyjnych kształcących tożsamość narodową. Nauka patriotyzmu opierała się na przekazywaniu wiedzy o Polsce, jej historii i kulturze, zwłaszcza poprzez symboliczne odwołania do polskiej tradycji, w tym świąt narodowych - 3 Maja i 11 listopada - nieuznawanych przez rząd socjalistyczny, a celebrowanych na obczyźnie w ramach troski o pamięć historyczną, tożsamość narodową i walkę o Niepodległą.
\end{abstract}

Słowa kluczowe: polska emigracja, Wielka Brytania, wychowanie patriotyczne, niepodległość, święta narodowe, edukacja.

Abstract: The article is devoted to the emigrant educational activity among Polish refugees in Great Britain after 1945. For Poles living outside the country patriotic education was one of the most important educational tasks shaping their national identity. The teaching of 
patriotism was based on the sharing of knowledge about Poland, its history and culture, especially through symbolic references to Polish tradition, including national holidays: 3 May and 11 November - not recognized by the socialist government in the country but celebrated abroad to preserve historical memory and national identity as well to struggle for Independent Poland.

Keywords: Polish emigration, Great Britain, patriotic education, Independence, national holidays, education.

Burzliwe dzieje Polski, a zwłaszcza lata walk o niepodległość to oprócz całej sfery faktów i wydarzeń politycznych, wojskowych, społecznych, ekonomicznych itp. również źródło potężnego ruchu emigracyjnego polskiej ludności, który rozpoczął się w pierwszej połowie XIX w. Historia Wielkiej Emigracji ma poczatek jeszcze w czasie trwania powstania listopadowego. Potem kolejne fale emigrantów, w tym Druga Wielka Emigracja po 1945 r., docieraja do różnych zakątków świata, by tam zamieszkać i nierzadko z dala od Ojczyzny walczyć o jej niepodległość - najpierw z zaborcami, potem z okupantem niemieckim i wreszcie komunistycznym rządem PRL oraz kolejnym okupantem - Związkiem Sowieckim. Jeden z nurtów tej walki stanowiła edukacja młodego pokolenia emigrantów.

Problematyka emigracji od lat jest aktualnym tematem i problemem naukowym, nad którym pochylają się politycy, nauczyciele, działacze, naukowcy (m.in. pedagodzy, historycy, poloniści) itp. Stanowi cel pracy instytucji rządowych i pozarządowych, by wymienić choćby Biuro ds. Kontaktu z Polakami za Granica przy Kancelarii Prezydenta RP, Instytut Pamięci Narodowej, Stowarzyszenie „Wspólnota Polska”, Związek Nauczycielstwa Polskiego (ZNP), Polską Macierz Szkolną Zagranica, Muzeum Emigracji w Gdyni, Narodowa Agencję Wymiany Akademickiej (NAWA) itp.

Szczególnym zagadnieniem jest działalność oświatowa w kręgach polskiej emigracji, do której zadań należy realizacja nie tylko celów poznawczych i kształcących związanych z nauką języka polskiego i wiedzą o Polsce oraz wartościach polskiej kultury, ale przede wszystkim patriotyczno-wychowawczych: nauka polskości i budowanie tożsamości narodowej poza granicami kraju. W czasach PRL-owskich dochodziła do tego jeszcze kwestia niepodległości, utrzymania wiary chrześcijańskiej oraz pamięci o polskiej historii, polskich bohaterach narodowych, polskich symbolach, świętach narodowych i znaczacych dla pamięci narodu miejscach, w tym także Kresach Wschodnich. Te ważkie zadania były przedmiotem troski działaczy na uchodźstwie. W poufnym dokumencie z obrad Wydziału Oświaty i Wychowania w Londynie z 24 V 1954 r. czytamy, że w związku ze znacznym wzrostem liczby szkół sobotnich nauczania ojczystego oraz liczby dzieci uczących się w tych szkołach (120 szkół, 3000 dzieci) „Zachodzi konieczność stworzenia odpowiedniej 
organizacji administracyjnej, która nadawałaby właściwy kierunek w dzie-

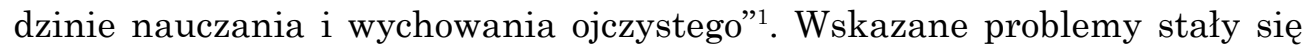
celami współpracy Wydziału Oświaty i Wychowania z wieloma organizacjami i stowarzyszeniami (m.in. Stowarzyszenie Polskich Kombatantów [SPK], Polska Macierz Szkolna [PMS], Zrzeszenie Nauczycielstwa Polskiego Zagranica, Komitety Mieszkańców Osiedli, komitety parafialne, placówki oświaty pozaszkolnej i szkoły, Komitety dla Spraw Oświaty Polaków, Ośrodek Korespondencyjny, harcerstwo, Towarzystwo Przyjaciół Dzieci i Młodzieży, Komitet Opieki nad Młodzieża Polska, Polski Instytut Katolicki) oraz centralnymi komórkami w Londynie patronujacymi działalności szkolnej (czyli np. Wydział Kulturalno-Oświatowy, SPK - Oddział Wielka Brytania, Zarząd Główny [ZG] PMS, ZG ZNP, Komisja Nauczania Przedmiotów Ojczystych przy Radzie Kulturalno-Oświatowej Zjednoczenia Polskiego) ${ }^{2}$. Aby zapobiec chaosowi spowodowanemu dużą liczbą zaangażowanych w kwestię oświaty placówek, powzięto postanowienie: „W dziedzinie [...] nadzoru pedagogicznego i kierunku nauczania i wychowania ojczystego należy sprawę postawić jasno i wyraźnie: Rząd Jedności Narodowej za pośrednictwem Wydziału Oświaty i Wychowania sprawuje w stosunku do całości organizowanych i utrzymywanych przez społeczeństwo szkół uprawnienia drugiej instancji szkolnej (przedwojenne Kuratorium Okręgu Szkolnego"”3. Uprawnienia te dotyczyły m.in. zatwierdzania organizacji szkoły i personelu nauczycielskiego, ustalania programu i metod nauczania, dokształcania nauczycieli, dostarczania materiałów (instrukcji, programów, książek, pomocy naukowych itp.) do centralnych stowarzyszeń polskich poza Wielką Brytania, podjęcia akcji wydawniczej

Znamienne dla emigracyjnej edukacji i postawionych przed nią zadań sa słowa wypowiedziane przez gen. Władysława Andersa 7 XII 1945 r. w trakcie uroczystego otwarcia roku szkolnego $\mathrm{w}$ gimnazjum i liceum dla ochotniczek Pomocniczej Służby Kobiet 2 Korpusu w Porto San Giorgio: „Idziemy do Polski Wolnej i Niepodległej. Droga nasza jest długa i ciężka. Musimy w tej drodze odbudować wszystko to, co tam w Kraju jest zburzone. [...] jeśli raz odstapi się od ideałów Honoru i Uczciwości, to zabrnie się w drogę bez wyjścia. Kraj patrzy na nas, jako na [...] oazę polskiej myśli, polskiego słowa... I dlatego [...] praca w tej szkole jest tak ważna"5, a w opracowanych w Londynie wytycznych działalności rządu RP w odniesieniu do spraw wyznaniowych, szkolnych, kulturalnych i oświatowo-wychowawczych z 23 IV 1965 r. w trzecim

\footnotetext{
${ }^{1}$ M. Goławski, Organizacja administracji polskich szkót sobotnich w Wielkiej Brytanii, Londyn, 24 maja 1954, w: Wybór dokumentów do dziejów polskiego uchodźstwa niepodlegtościowego 1939-1991, oprac., red. A. Suchcitz, L. Maik, W. Rojek, Londyn 1997, nr 55, s. 297.

2 Ibidem, s. 299-300.

${ }^{3}$ Ibidem, s. 300.

${ }^{4}$ Ibidem, s. 300-302.

${ }^{5}$ Generał broni Władystaw Anders. Wybór pism i rozkazów, wstęp, wybór, oprac. B. Polak, Warszawa 2009, s. 230.
} 
akapicie czytamy: „Dzieci te [tj. urodzone poza krajem polskim - D.J.G.] należy utrzymać przy polskości nie szczędząc wszelkich ofiar. [...] Rząd RP i większość społeczeństwa polskiego przebywającego na przymusowym uchodźstwie, zdaja sobie sprawę z powyższych faktów i dlatego podejmuja

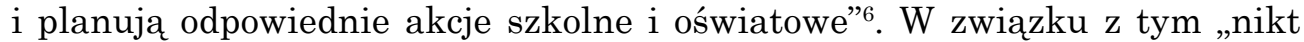
nie może uchylać się od pomocy w wykonywaniu najważniejszego zadania, którym jest utrzymanie w polskości młodego pokolenia zrodzonego i wychowanego na emigracji”, a także wychowanie i przygotowanie go „według zasad chrześcijańskich oraz zachęcanie jej do walk i pracy o przywrócenie Polsce Suwerenności, Niepodległości i Wolności”"

Pomimo świadomości wagi problemu początki zorganizowanej edukacji na obczyźnie były bardzo trudne ${ }^{9}$, o czym piszą w swoich pracach choćby Tadeusz Radzik $^{10}$ oraz inni badacze zajmujący się tą problematyka ${ }^{11}$. Sprawy nie ułatwiało też rozproszenie polskich emigrantów. Tadeusz Kondracki określając zasięg polskiego życia społecznego na brytyjskiej prowincji, w tym polskiej oświaty, zaznaczył, że polskie osadnictwo dotyczyło początkowo aż kilkuset ośrodków, od północnej Szkocji po południowe rejony Anglii ${ }^{12}$.

Wstępnie „Pracę oświatową na emigracji wojennej i powojennej oparto z konieczności na programach [i podręcznikach - D.J.G.], które obowiązywały w kraju przed katastrofą wrześniowa" ${ }^{13}$, co oznaczało konieczność dostosowania podręczników i opracowania nowego programu. Planowa akcja wydawnictw

${ }^{6}$ Wytyczne działalności rzadu RP $w$ odniesieniu do spraw wyznaniowych, szkolnych, kulturalnych i oświatowo-wychowawczych. Londyn, 23 kwietnia 1965, w: Wybór dokumentów..., nr 97 , s. 469.

7 Ibidem, s. 472.

8 Ibidem, s. 473.

${ }^{9}$ Por. M. Goławski, Organizacja administracji..., s. 297.

${ }_{10}$ Por. T. Radzik, Szkolnictwo polskie w Wielkiej Brytanii po drugiej wojnie światowej, Lublin 1991; idem, Historia Zrzeszenia Nauczycielstwa Polskiego za Granica 1941-1991, Londyn 1999; idem, Z dziejów społeczności polskiej w Wielkiej Brytanii po drugiej wojnie światowej (1945-1990), Lublin 1991; idem, Polska diaspora w Wielkiej Brytanii, w: Polska diaspora, red. nauk. A. Walaszek, Kraków 2001, s. 149-166.

${ }^{11}$ Por. K. Ludzińska, Szkolnictwo polskie w Wielkiej Brytanii, „Studia Polonijne” (Lublin) 1983, t. VII, s. 127-150; O. Zamecka-Zalas, Pedagodzy - zastużeni dla zachowania tożsamości narodowej Polaków na uchodźstwie po II wojnie światowej (na przyktadzie organizacji Polska Macierz Szkolna), w: Dom rodzinny w doświadczeniu (auto)biograficznym, red. A. Ładyżyński, M. Piotrowska, M. Kasprzak, Wrocław 2017, s. 201-216; Paryż - Londyn - Monachium - Nowy Jork. Powrześniowa emigracja niepodlegtościowa na mapie kultury nie tylko polskiej, t. II, red. V. Wejs-Milewska, E. Rogalewska, Białystok 2016; A. Pędrak, Szkolnictwo polonijne w Wielkiej Brytanii i Irlandii, 2017, http://dx.doi.org/10.18778/8088705-3.02 (dostęp: 18 IX 2018).

12 T. Kondracki, Historia Stowarzyszenia Polskich Kombatantów w Wielkiej Brytanii 1946 1996, Londyn 1996.

${ }^{13}$ J. Dąbrowski, Z rozważań o wychowaniu, „Wiadomości Nauczycielskie”, I-III 1946, nr 7-9, s. 3. 
podręczników i pomocy naukowych dla szkół nauczania ojczystego należała do zadań Wydziału Oświaty i Wychowania i miała być realizowana z pomoca $\mathrm{PMS}^{14}$. Jeśli chodzi o podręczniki, to zmian dokonywano głównie w części literackiej i dla najmłodszych uczniów, o czym będzie jeszcze mowa w związku z podręcznikiem Benedykta Kubskiego, Mieczysława Kotarbińskiego i Ewy Zarembiny ${ }^{15}$. Sporo dyskusji wzbudzał zalecany do edukacji podstawowej Elementarz Mariana Falskiego ${ }^{16}$, wydany po raz pierwszy pt. Nauka czytania $i$ pisania dla dzieci w 1910 r. ${ }^{17} \mathrm{i}$ uznany za jeden z najlepszych na świecie na międzynarodowej wystawie podręczników dla dzieci w Brukseli, m.in. za nowatorskie podejście do nauki pisania i czytania ${ }^{18}$. W okresie międzywojennym ukazały się wersje elementarza dla dzieci miejskich, wiejskich, dla żołnierzy i cywilnych analfabetów ${ }^{19}$. Drukowany na obczyźnie ${ }^{20}$ służył dzieciom jeszcze wiele lat. W Polsce Ludowej powojenny elementarz dla dzieci, opracowany na nowo, ocenzurowany i uwzględniajaccy elementy obowiązkowej w tym czasie ideologii komunistycznej (aczkolwiek bez wymieniania

${ }^{14}$ Por. M. Goławski, Organizacja administracji..., s. 298, 302.

15 B. Kubski, M. Kotarbiński, E. Zarembina, Czytanka dla III klasy miejskich szkót powszechnych, Lwów 1934 [nakład i własność K.S. Jakubowskiego, Lwów]; iidem, Czytanka dla III klasy szkót powszechnych, Jerozolima 1943.

${ }^{16}$ Por. „Wydanie przedwojenne jest już przestarzałe tak pod względem tematyki, jak i strony zewnętrznej”. M. Goławski, Organizacja administracji..., s. 301. Zob. też: A. Bogusławska, Czy potrzebny jest nowy Elementarz?, „Wychowanie Ojczyste”, III-IV 1956, nr 3, s. 1-7.

${ }^{17}$ „W latach 1921 i 1926 pojawiły się nowe wersje podręcznika Falskiego. Nosiły one tytuł Elementarz powiastkowy dla dzieci. W roku 1933 Falski opracował dwie wersje elementarza: tematyczny - Elementarz dla szkót miejskich i powiastkowy - Elementarz dla szkót wiejskich (kolejne wydanie tych podręczników nastapiło w 1937). W okresie II wojny światowej nastapiła przerwa w wydawaniu Elementarza, gdyż okupacyjne władze niemieckie zabroniły używania tej książki. W tajnym nauczaniu rozpowszechniano jedynie jej odpisy. W roku 1949 ukazał się po raz pierwszy kolorowy ujednolicony Elementarz dla wszystkich uczniów klasy I, zarówno ze szkół miejskich, jak i wiejskich. Stał się on obowiązującym podręcznikiem szkolnym. Osiem lat później (1957/58) Falski wprowadził do Elementarza kolejne zmiany. W wydaniu tym znalazły się m.in. wiersze Tuwima, Fredry, Słonimskiego. Uzupełnieniem Elementarza były Ćwiczenia elementarzowe. W roku 1968 Falski przedstawił Ministerstwu Oświaty i Wychowania udoskonalony projekt podręcznika. Został on wydany dopiero w roku 1975, już po śmierci autora”. M. Bober-Pełzowska, J. Tuzimek, Nauka czytania i pisania w elementarzach Mariana Falskiego, w: Problemy psychodydaktyki nauczania poczatkowego, red. M. Przetacznik-Gierowska, Warszawa 1992; E. Brańska, Zapomniany autor Elementarza, „Wychowanie w Przedszkolu” 2005, nr 10, s. 13-17, cyt. za: A. Jurek, W czym tkwi fenomen Elementarza Falskiego, http://www.reedukacja.pl/ default.aspx?action=view\&item=586 (dostęp: 2 X 2018).

18 A. Jurek, op. cit.

19 J.A. Szczepański, To byt elementarz!, Nowiny24, https://nowiny24.pl/to-byl-elementarz/ ar/5921087 (dostęp: 12 X 2018).

${ }^{20}$ Por.: ,[...] dotychczas tylko Skarb Narodowy podją akcję wydawniczą w postaci przedruku przedwojennego wydania elementarza M. Falskiego". M. Goławski, Organizacja administracji..., s. 301 . 
postaci Stalina), ukazał się po raz pierwszy w $1949^{21}$, a po raz ostatni w 1982 r. $^{22}$ (później pojawiały się jeszcze kolejne wydania, głównie jako reprinty, a nie programowe podręczniki szkolne). „Wznowiony przez WSiP po kilkunastu latach, w wersji z 1973 roku, wzbudził ogromne zainteresowanie, szczególnie wśród Polonii” ${ }^{23}$.

Do wydanego w Londynie w latach czterdziestych Elementarza Zygmunt Nowakowski napisał Przedmowę:

„Kto chlebem gardzi, to nim Pan Bóg jeszcze bardziej” - mówi stare przysłowie. Język polski to nasz chleb. Gdy dziecko z psoty rzuci kawałek chleba na ziemię, zwykliśmy je karcić mówiąc: „Podnieś natychmiast i pocałuj!” Podobnie, gdy młodsze pokolenie Polaków na uchodź[s]twie odwraca się od polskiej mowy, gdy się jej zaczyna wypierać albo wstydzić i odrzucać, powinniśmy upominać je, mówiąc: „Podnieś i pocałuj, bo to jest najpiękniejszy język na świecie, język, w którym matka uczyła cię pacierza!" Lecz zamiast karcić, lepiej budzić u młodzieży i u dzieci miłość mowy polskiej. Walcząc o język, walczymy równocześnie o ziemię polska, o wolność. Język wytycza granice naszej ojczyzny, świadcząc, jak daleko sięgała, sięga i sięgać będzie Polska. Kto mówi, czyta, pisze i modli się po polsku, ten zawsze duszą jest w Polsce. Język to nasz skarb narodowy. Baczmy, byśmy go nie roztrwonili po drodze. Pilnujmy, by zachował całe swe bogactwo i piękno ${ }^{24}$.

W przedmowie Do Rodziców $i$ Wychowawców w kolejnym londyńskim wydaniu elementarza z 1954 r. Zygmunt Rusinek, minister dla spraw obywateli polskich na obczyźnie, tłumaczył:

Jedna z [...] potrzeb, silnie i powszechnie odczuwanych wśród nas, jest potrzeba uczenia dzieci języka polskiego. Choć rozsypani, stanowimy społeczeństwo, mające wolę przekazania swym dzieciom mowy, będącej wynikiem naszej własnej kultury narodowej, wytworzonej na przestrzeni dziejów. [...] Rząd Polski i Główna Komisja Skarbu Narodowego pragna [...] skierować myśli i uczucia dziecka ku Ojczyźnie; jest ona jednym z pierwszych powiązań dziecka z jego Narodem, szczególnie ważnym poza granicami kraju na obczyźnie. Nasz elementarz nie zawiera błędnych idei, jak to bywa w wydaniach krajowych ${ }^{25}$.

W wydaniu PRL-owskim pojawiło się dużo czytanek podkreślających trud ludzi pracy (murarz, kominiarz ${ }^{26}$, aptekarz ${ }^{27}$, rolnik itp. ${ }^{28}$ ), zwłaszcza jednak

${ }^{21}$ M. Gliński, Marian Falski, autor kultowego „Elementarza” urodzit się 130 lat temu, culture.pl, https://culture.pl/pl/artykul/marian-falski-autor-kultowego-elementarzaurodzil-sie-130-lat-temu (dostęp: 20 X 2018).

${ }^{22}$ E. Brańska, op. cit., s. 14.

${ }^{23}$ Ibidem.

${ }_{24}$ Z. Nowakowski, Przedmowa, w: M. Falski, Elementarz, Londyn 1940, s. 3.

${ }_{25}$ Z. Rusinek, Do Rodziców i Wychowawców, w: M. Falski, Elementarz z rysunkami Wacława Borowskiego, Londyn 1954, s. 3.

${ }^{26}$ M. Falski, Elementarz, Warszawa 1949, s. 145.

${ }^{27}$ Ibidem, s. 147.

${ }^{28}$ Ibidem, s. 126, 127, 144. 
tych pracujących w hucie i fabryce: „Chętnie wszystko robią i pracy nie żałuja" ${ }^{29}$, ukazany też w formie poetyckiej w wierszu Juliana Tuwima Wszyscy dla wszystkich ${ }^{30}$ (utwór napisany pod koniec międzywojnia). Wspomniana została również Nowa Huta, do której przeprowadza się z rodziną kolega z klasy i bardzo się z tego cieszy ${ }^{31}$. Szeroko rozbudowano watek przyjaźni między dziećmi z różnych krajów, podkreślony ponownie przez wiersz Tuwima $B_{a m b o}^{32}$ (napisany w 1935 r.) i zwieńczony opisem 1 Maja opatrzonego ilustracja która wskazuje zaprzyjaźnione kraje poprzez trzymane przez dzieci choragiewki w barwach narodowych - sa to, jak nietrudno się domyślić, kraje socjalistyczne $^{33}$. W ramach nauki o Polsce dzieci mogły przeczytać $\mathrm{w}$ jednym z tekstów opisujaccych lekcję: „Polska jest nasza ojczyzną. Warszawa jest naszą stolica. A nasz hymn narodowy - Jeszcze Polska nie zginęta", zaś radio uczyło je śpiewać: „Płynie Wisła, płynie / Po polskiej krainie / A dopóki płynie / Polska nie zaginie" ${ }^{34}$. Ponadto w elementarzu znalazł się ${ }^{35}$ drukowany też w nim w międzywojniu ${ }^{36}$ wiersz o Warszawie (w dwudziestoleciu ilustrowany wizerunkiem kolumny Zygmunta, a w PRL-u - rycina przedstawiająca Trasę W-Z), natomiast został usunięty tekst o Orle Białym - godle Polski, który poprzedzał wiersz Tuwima Abecadto. W wydaniach dla dzieci polonijnych tekst oczywiście zachowano, a ilustrował go czarno-biały schemat orła w koronie: „To Orzeł Biały - godło Polski. Powiedzcie, gdzie to godło widzimy. Jest ono na polskich pieniądzach i na polskich znaczkach pocztowych. Widzimy je na czapkach u naszych żołnierzy. Widzimy je w mieście na wielu gmachach. Mamy to godło i na naszej szkole. Mamy je i na naszym sztandarze szkolnym, z którym maszerujemy w dni uroczyste" ${ }^{37}$. Ostatnie zdanie jest jedynym nawiązaniem do świąt narodowych.

Podręczniki z zakresu kształcenia językowego z międzywojnia drukowano bez zmian, tyle że poza granicami kraju, np. podręczniki autorstwa Zenona Klemensiewicza Język polski. Ćwiczenia i pogadanki gramatyczne do gimnazjum, wydawane w 1934 r. przez Książnicę-Atlas w Warszawie i Lwowie, drukowano w Jerozolimie w $1943 \mathrm{r}^{38}$

W ramach przygotowania do nauczania polskości Ministerstwo Wyznań Religijnych i Oświecenia Publicznego podjęło akcję wydawnicza, dzięki której

${ }^{29}$ Ibidem, s. 87, 149.

${ }^{30}$ Ibidem, s. 147.

${ }^{31}$ Ibidem, s. 150.

${ }^{32}$ Ibidem, s. 161.

${ }^{33}$ Ibidem, s. 162.

${ }^{34}$ Ibidem, s. 123.

${ }^{35}$ Ibidem, s. 166.

${ }^{36}$ M. Falski, Elementarz, Lwów 1937, Londyn 1954, s. 156.

${ }^{37}$ Ibidem (1937), s. 128.

${ }^{38}$ Z. Klemensiewicz, Język polski. Ćwiczenia i pogadanki gramatyczne dla II klasy gimnazjalnej, Warszawa-Lwów 1934; idem, Język polski. Ćwiczenia i pogadanki gramatyczne dla II klasy gimnazjalnej, Jerozolima 1943. 
pojawiło się wiele pozycji, w tym obok podręczników (dla szkół powszechnych ${ }^{39}$, dla gimnazjum i liceum ${ }^{40}$, z zakresu techniki ${ }^{41}$, ekonomii i handlu ${ }^{42}$ ), czasopism (,Ognisko Harcerskie” - miesięcznik organizacyjny Naczelnego Komitetu Związku Harcerstwa Polskiego [ZHP], tylko dla członków ZHP; „Zuch” dwutygodnik dla młodzieży, Londyn; „Skaut” - miesięcznik Komendy ZHP na Bliskim Wschodzie ${ }^{43}$ ) i innych wydawnictw dla harcerzy oraz Polonii na Bliskim Wschodzie ${ }^{44}$ (w tym wydawnictwa powielane ${ }^{45}$ i tłumaczone ${ }^{46}$ ) m.in. seria pod wiele znaczacym tytułem: Pomniki Literatury Ojczystej (Londyn) ${ }^{47}$ (w skład weszło 5 tomów, a łącznie 9 zeszytów, poświęconych literaturze polskiej: opracowania ogólne „Od Bogarodzicy do Mickiewicza” oraz zeszyty monograficzne poświęcone poszczególnym polskim pisarzom, tj. Adamowi Mickiewiczowi, Juliuszowi Słowackiemu, Zygmuntowi Krasińskiemu, Stanisławowi Wyspiańskiemu i Janowi Kasprowiczowi).

Jolanta Chwastyk-Kowalczyk przypomniała, że we Włoszech przy Wojsku Polskim funkcjonował oddział Polskiego Czerwonego Krzyża organizujacy dla polskich dzieci przedszkola i szkoły, co zrodziło potrzebę wydrukowania książek dla wszystkich klas oraz powołania do życia czasopisma, które pomogłoby nauczycielom i uczniom w procesie edukacji ${ }^{48}$. „Przy 2. Korpusie Polskich Sił Zbrojnych w Bari we Włoszech, dzięki inicjatywie płk. Stanisława Tworzydło ${ }^{49}$ i Natalii Biętkowskiej, ukazał się w styczniu 1946 r. w Bari we Włoszech miesięcznik dla młodzieży "Dziatwa»" ${ }^{50}$. Pismo wraz z ewakuowanym wojskiem przybyło do Wielkiej Brytanii. Dokładnie rzecz biorąc, pierwszych 10 numerów „Dziatwy” ukazało się we Włoszech w Foxley Camp, a numer 11 z 1946 r. opublikowano już na Wyspach Brytyjskich. Kolejnymi wydawcami byli Zjednoczenie Polskie w Wielkiej Brytanii, a następnie Polska Macierz Szkolna Zagranica.

${ }^{39}$ Informator Ministerstwa Wyznań Religijnych i Oświecenia Publicznego, Londyn 1945, s. $40-42$.

${ }^{40}$ Ibidem, s. $42-44$.

${ }^{41}$ Ibidem, s. 44.

${ }^{42}$ Ibidem, s. 44-45.

${ }^{43}$ Ibidem, s. 45.

${ }^{44}$ Ibidem, por. s. $45-49$.

${ }^{45}$ Ibidem, s. 46-47, 49-50.

${ }^{46}$ Ibidem, s. 50, por. „Akcja Przekładów Wydawnictw Pedagogicznych”.

${ }^{47}$ Ibidem, s. 40.

48 J. Chwastyk-Kowalczyk, Polskie czasopisma emigracyjne wspierajace edukacje $w$ Wielkiej Brytanii w latach 1946-2017, „Przegląd Historyczno-Oświatowy” 2017, nr 1-2, s. 137.

${ }^{49}$ Stanisław Tworzydło - podpułkownik Wojska Polskiego, były kierownik Sekcji Wydawniczej 2 Korpusu, urodzony we Lwowie 14 XII 1897 r., zmarł w Londynie 6 XII 1952 r. - na podstawie nekrologu, „Dziennik Polski i Dziennik Żołnierza” 1952, nr 296, s. 4, cyt. za: J. Chwastyk-Kowalczyk, op. cit., s. 137.

${ }^{50}$ J. Kowalik, Bibliografia czasopism polskich wydanych poza granicami kraju od września 1939 roku, t. I, Lublin 1976, s. 144-145, poz. 582, cyt. za: J. Chwastyk-Kowalczyk, op. cit., s. 137. 
W pierwszym numerze pisma redaktorka Natalia Biętkowska zwróciła się do dzieci w datowanym na 1 XII 1945 r. liście:

Kochane Dzieci!

Dawno już myślałam, żeby dać Wam, wygnanym z domów rodzinnych i rozproszonych po całym świecie, pismo, które dotarłoby do Was Wszystkich, w którym wypowiadałybyście się, i na łamach którego nawiązałybyście łączność między soba, dzięki czemu znów stałybyście się jedną WIELKĄ RODZINĄ POLSKICH DZIECI ${ }^{51}$.

Nie zapomniano również o nauczycielach. Zgodnie z postulatami zdajacych sobie sprawę z potrzeb i problemów nauczycieli uczestników Zjazdu Polskich Nauczycieli Szkół Średnich i Powszechnych w Perth w Szkocji w 1941 r. powołano do życia miesięcznik „Przegląd Pedagogiczny” pod redakcją dr. Mieczysława Pawłowskiego, a w 1954 r. w Leeds podczas pierwszej konferencji rejonowej Zarząd PMS podjął decyzję o wydawaniu „Wychowania Ojczystego” - czasopisma dla nauczycieli Polskich Szkół Przedmiotów Ojczystych w Wielkiej Brytanii. W 1955 r. ukazał się pierwszy numer pisma, który w 1984 r. przekształcono w „Wychowanie i Słowo Ojczyste”, następnie w „Słowo Ojczyste”

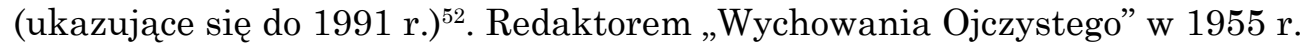
został Michał Goławski ${ }^{53}$. Równie poczytnym czasopismem metodycznym były też „Wiadomości Nauczycielskie”.

Co zaś się tyczy programu nauczania w szkołach na obczyźnie, to pierwszy wariant, tzw. tymczasowy, ukazał się w 1952 r. w Londynie. W 1955 r. opublikowano dopracowaną wersję wydaną przez Zrzeszenie Nauczycielstwa Polskiego Zagranica: Program nauki w szkołach przedmiotów ojczystych ${ }^{54}$. Zgodnie z nim edukacja dzieci i młodzieży polskiej emigracji w ramach szkoły powszechnej została podzielona na pięć poziomów kształcenia:

I. Poziom elementarny (wiek 5-6 lat)

II. Poziom elementarny starszy (wiek 6-7 lat)

III. Poziom początkowy (wiek 7-9 lat)

IV. Poziom średni (wiek 9-11 lat)

V. Poziom wyższy (wiek 11-13 lat).

W zakresie powyższych poziomów, oprócz nauki podstawowych umiejętności (mówienie, pisanie), dużo miejsca planowano poświęcić na bogacenie

${ }^{51}$ N. Biętkowska, List do Dzieci, „Dziatwa” 1946, nr 1, s. 32, cyt. za: J. Chwastyk-Kowalczyk, op. cit., s. 138.

52 J. Chwastyk-Kowalczyk, op. cit., s. 145.

${ }^{53}$ Kontynuował tę pracę nieprzerwanie przez ponad 19 lat. Zmarł 2 VI 1974 r. Redagował „Wychowanie Ojczyste” właściwie aż do śmierci, nie doczekał jednak dwóch jubileuszy 20-lecia swojej pracy redaktorskiej oraz setnego numeru pisma. Numer 99 periodyku był ostatnim pod jego redakcja. Ibidem, s. 147, przypis 45 .

${ }^{54}$ Program nauki w szkołach przedmiotów ojczystych na szczeblu szkoły powszechnej, wyd. 3, Londyn 1955; Tymczasowy Program Nauczania Przedmiotów Ojczystych, wyd. 1, Londyn 1952, wyd. 2, Londyn 1954. 
słownictwa $\mathrm{w}$ związku ze wskazanymi tematami (rodzina, dom, przeżycia itp.) i wybranymi tekstami kultury (literatura polska - proza i poezja) ${ }^{55}$. Ponadto wśród obowiązkowych haseł programowych na wszystkich poziomach (z dostosowanym stopniem trudności) znalazły się pogadanki okolicznościowe w związku ze świętami narodowymi i kościelnymi (z nawiązaniem do polskich zwyczajów), wiersze i czytanki patriotyczne oraz proponowane tematy do rozmów: „Aktualne wydarzenia ze szczególnym uwzględnieniem wydarzeń w Polsce. [...] Polskie zwyczaje i obyczaje: dożynki, lajkonik, zapusty, Kaziuk, kulig itd.)" ${ }^{56}$ (poziom IV) i ćwiczenia w mówieniu „w związku z [...] historią: święta narodowe i rocznice $\mathrm{w}$ oparciu o wiadomości z historii. Omawianie obrazów historycznych, odczytywanie akcji” ${ }^{57}$. W Rocznym rozkładzie materiału nauczania dla poziomu początkowego w dziale „Wiadomości z historii i geografii" pojawiły się hasła programowe:

POJĘCIE WYRAZU OJCZYZNA - KRAJ RODZINNY - Rówieśnik w Polsce - a ja. Rodak a Wygnaniec. Dlaczego nie wracamy. Jak moi rodzice znaleźli się w Anglii. Gdzie mieszkali w Polsce. [...]

Mapa Polski. Co to jest żelazna kurtyna - Ziemie zabrane i odzyskane (na tle stosunków rodzinnych dzieci - dokąd idą listy i paczki) ${ }^{58}$.

Autorka przywoływanego już rozkładu materiału, M. Duszowa instruowała też:

Śpiew należy traktować okolicznościowo dla odprężenia, oraz w korelacji z tematyka j. polskiego, tudzież wiadomości z historii z geografia. [...] Takie piosenki jak Piosnka żaków; A ta śliczna Wista; Bartoszu, Bartoszu, [...] Na Wawel, na Wawel; Piękna nasza Polska cała, kaszubska Hej - żeglarze nadają się świetnie na obchody świąt narodowych - popisów szkolnych i są zaczerpnięte z naszej skarbnicy narodowej ${ }^{59}$.

Wśród wskazówek dydaktycznych wspominanego już, uznanego autorytetu pedagogicznego z kręgów PMS w Londynie, Michała Goławskiego ${ }^{60}$ znalazły się wytyczne: „Aby Polskę przybliżyć dziecku, wytworzyć atmosferę polskości, podbudować tło dla nauki języka, trzeba wprowadzić [...] legendy, opowiadania historyczne i geograficzne o miastach, rzekach, morzu, górach, ludziach i zwyczajach” (poziom III - początkowy) ${ }^{61}$, bowiem „Całość nauczania ma

${ }^{55}$ Program nauki $w$ szkołach..., s. 23-26.

${ }^{56}$ Ibidem, s. 27.

57 Ibidem, s. 28.

${ }^{58}$ M. Duszowa, Roczny rozkład materiału nauczania (cz. I. Okres do Bożego Narodzenia). Poziom poczatkowy, „Wychowanie Ojczyste”, IX-X 1956, nr 6, s. 17.

${ }^{59}$ Ibidem. W przywołanym cytacie, ze względu na rażące usterki interpunkcyjne w tekście oryginalnym, zastosowano poprawną interpunkcję, by ułatwić zrozumienie przekazu.

${ }^{60}$ Michał Goławski (1904-1974) - mgr, pedagog; redaktor „Wychowania Ojczystego” - pisma PMS; prezes ZG PSM, członek Wydziału Oświaty i Wychowania; cyt. za: M. Goławski, Organizacja administracji..., nr 55, s. 297, przypis 2, s. 303.

${ }^{61}$ Ibidem, s. 5-6. 
obudzić, rozwinąć i utrzymać poczucie odrębności narodowej polskiej i ukazać dziecku nieznaną ojczyznę - Polskę"

Tak sformułowanym wymaganiom i celom kształcenia podporządkowane zostały przedmioty nauczania, zwane przedmiotami ojczystymi:

1) religia w wyznaniu dziecka

2) język polski jako ojczysty

3) pogadanki z historii ojczystej i historia Polski

4) krajoznawstwo i geografia Polski w połączeniu z przyrodą kraju ojczystego

5) polski folklor w pieśni, tańcu, muzyce i sztuce

6) zamiłowanie do polskiej książíi ${ }^{33}$.

Znaczenie edukacji narodowej podkreślano wielokrotnie zarówno w mowach polityków, jak i materiałach dydaktycznych:

Środowisko każdej emigracji, niezależnie od jej charakteru politycznego czy gospodarczego, winno dbać o wychowanie narodowe swych dzieci, w oparciu o wartości kultury narodowej i przeszłości kraju macierzystego. [...] Warunki w jakich żyjemy, oderwani od Kraju, do którego nie mamy nie tylko dostępu, ale nawet normalnego kontaktu z naszymi najbliższymi, stwarzają tym bardziej konieczność narodowego polskiego wychowania naszych dzieci ${ }^{64}$.

Za fundamenty idei wychowania ojczystego na emigracji uznano trzy elementy:

1) wiarę - religię

2) „poczucie przynależności każdego z nas do narodu polskiego, wraz z jego językiem [...], jego historia, tradycja, obyczajami, dorobkiem cywilizacyjnym i wielowiekową kultura moralną i materialna, wraz z polskim stylem życia" (m.in. polski folklor) ${ }^{65}$

3) „stale wpajana świadomość, że jako forma organizacji naszego narodu istnieje Państwo Polskie [podkreślenie-D.J.G.], wskrzeszane wysiłkiem pokoleń do dawnego, wiekowego bytu i uznane przez cały świat współczesny”66.

Dydaktyczno-patriotyczne cele nie tylko były firmowane przez wypowiedzi polityków czy programy nauczania. Autorzy podręczników kierowali je także bezpośrednio do uczniów, np. w podręczniku do nauczania geografii Kraj swój - choć daleki. Polska w opisie i obrazach, wydanym w 1956 r. w Londynie ${ }^{67}$, na pierwszej stronie witało dzieci motto autorstwa Wincentego Pola: Pieśn

\footnotetext{
${ }^{62}$ M. Goławski, Wychowanie ojczyste na emigracji, „Wychowanie Ojczyste”, XI-XII 1955, nr 1 , s. 5 .

${ }^{63}$ Ibidem.

${ }^{64}$ Ibidem, s. 3.

${ }^{65}$ Ibidem.

${ }^{66}$ Ibidem.

${ }^{67}$ I. Broniatowska, Kraj swój - choć daleki. Polska w opisie i obrazach, Londyn 1956.
} 
o ziemi naszej (,A czy znasz ty, bracie młody, / Twoje ziemie, Twoje wody / [...] Pola bitew - ojców groby - / I pomniki starej doby?"68), natomiast żegnało ważne przesłanie. Pod nagłówkiem „POZNAĆ LEPIEJ OJCZYZNE, ŻEBY JA POKOCHAĆ” dzieci czytały: „My wygnańcy staramy się odtworzyć oblicze Ojczyzny na podstawie przystępnych nam źródeł. [...] Zbroimy się w wiedzę o naszym Kraju dalekim, by móc doń wrócić jak do domu i stanąć do warsztatu pracy z pożytkiem dla Ojczyzny wtedy, kiedy to będzie możliwe"69.

Co ciekawe, w tym samym podręczniku (do geografii Polski) autorka zwróciła uwagę na ważną korelację wskazaną już wstępnie w słowach motta: „Nieprzebrane bogactwo opisów Kraju znajdujemy w polskiej powieści i poezji. Dobrze jest pamiętać o tym związku twórczości literackiej z ziemią i starać się go zrozumieć"70. Wszak podstawą kształcenia narodowego są język, literatura i kultura kraju.

W podręcznikach do kształcenia polonistycznego patriotyczny cel nauczania polskości i niepodległości wyraźnie eksponowano często już w samym tytule, np. U progu Polski ${ }^{71}$ czy $W$ kręgu dzielności i pracy ${ }^{72}$. Ponadto znajdujemy go w notkach do uczniów, umieszczonych na pierwszych stronach, np.: „Oddajemy ten podręcznik młodzieży polskiej do użytku w szkołach przedmiotów ojczystych i w domach rodzinnych. Podręcznik został wydany dzięki ofiarności społeczeństwa polskiego na emigracji na "DAR NARODOWY 3 MAJA» - Polska Macierz Szkolna Zagranica" "73. Akcja, dzięki której wydano m.in. wspomniany podręcznik, była ogłaszana w odezwach „Do Polaków na świecie” publikowanych na łamach „Wychowania Ojczystego” z okazji majowego święta przez PMS:

DAR NARODOWY 3 MAJA - powszechna narodowa danina, składana przez wszystkich Polaków na rzecz oświaty polskiej na obczyźnie. DAR NARODOWY 3 MAJA daje konieczną broń do dalszej walki o polskość polskich dzieci na obczyźnie. POLSKA MACIERZ SZKOLNA nie ma majątku. Rozwój jej działalności oświatowo-szkolnej i wydawniczej zależy od wyniku zbiórki na DAR NARODOWY, od ofiarności społeczeństwa polskiego na emigracji ${ }^{74}$.

„Współdziałając zgodnie, gdziekolwiek losy nas rzuciły - w obchodzie Święta Narodowego - dajmy wyraz naszej trosce o polskość młodego pokolenia emigracyjnego. Dajmy broń do dalszej walki o polskie oblicze tego pokolenia,

68 Ibidem.

${ }^{69}$ Ibidem, s. 64.

${ }^{70}$ Ibidem.

71 S. Tync, J. Gołąbek, J. Duszyńska, U progu Polski. Czytanka polska dla IV klasy szkoty powszechnej, Jerozolima 1943.

72 J. Otwinowska, W kręgu dzielności i pracy. Podręcznik do nauki języka polskiego dla klasy VI, Londyn 1966.

${ }^{73}$ Ibidem, s. 4.

74 Odezwa do Polaków w świecie, „Wychowanie Ojczyste”, III-IV 1958, nr 2; por. też: Odezwa do Polaków w świecie, „Wychowanie Ojczyste”, III-IV 1957, nr 9. 
składając hojne ofiary na DAR NARODOWY 3 MAJA"75. Odezwę podpisał m.in. gen. Władysław Anders jako przewodniczący Rady PMS.

Narodowy cel edukacyjny zawarty był także w spisach treści, w których znalazły się działy: „KU WOLNOŚCI”, „WYBITNI POLACY W ŚWIECIE I W KRAJU”, „DZIELNI I WYTRWALI”, „W POLSCE ODRODZONEJ”, „Z NIEDAWNEJ PRZESZŁOŚCI”76 czy też „PIEŚŃ O ZIEMI NASZEJ, KU WOLNOŚCI I POTĘDZE”"77. Pojawił się również we wprowadzeniu do spisu rozdziałów jako krótki opis treści i układu:

Tematyka obejmuje okres od epoki stanisławowskiej po czasy drugiej wojny światowej, uwzględniając walki o wolność i najistotniejsze wartości narodu oraz wkład wybitnych jednostek i społeczeństwa do naszego dorobku kulturalnego.

Opowiadania są dobierane z myślą o ukazaniu w formie beletrystycznej przekroju ważniejszych wydarzeń, tak, by naświetlały atmosferę poszczególnych okresów, dając ogólny obraz wysiłków z uwzględnieniem roli młodzieży i jej udziału w życiu narodu ${ }^{78}$.

Dobór treści w większości podręczników do nauczania języka polskiego w szkołach powszechnych dotyczył określonych kręgów tematycznych:

- Sławni Polacy (politycy, wojskowi, królowie, artyści, pisarze, naukowcy, np. gen. Jan Henryk Dąbrowski, Marszałek Józef Piłsudski, Zygmunt II August, Stanisław August Poniatowski, Jan Matejko, Fryderyk Chopin, Stanisław Moniuszko, Adam Mickiewicz, sir Paweł Edmund Strzelecki, Mikołaj Kopernik, Jan Śniadecki, Maria Skłodowska-Curie);

- Ważne wydarzenia i zjawiska historyczne (bitwa pod Grunwaldem, powstanie listopadowe, powstanie styczniowe, germanizacja, rusyfikacja, legiony Dąbrowskiego, bunt dzieci z Wrześni, lipiec 1915 - walki Pierwszej Brygady Legionów na terenie Lubelszczyzny, Polska Organizacja Wojskowa, 11 listopada 1918 r., Bitwa Warszawska 1920, wrzesień 1939 r., Powstanie Warszawskie);

- Symbole narodowe (polski hymn, czapka z orzełkiem, choragiew wolności, język polski - polska szkoła, Grób Nieznanego Żołnierza, polskie serce, polskie kwiaty, bociany, Cmentarz Obrońców Lwowa; sztuka polska: muzyka Chopina, polonezy, mazurki; obrazy Matejki - dzieje Polski);

- Święta narodowe (11 listopada, 3 Maja) i religijne (Boże Narodzenie, Wielkanoc, Niedziela Palmowa);

- Polskie zwyczaje i obyczaje (Zaduszki, Barbórka, wianki na Wiśle, kolędnicy, święcone, pisanki, lajkonik, dożynki, sobótka);

- Ważne miejsca (Wilno, Lwów, Gdynia, Warszawa, Kraków, Wawel, Jasna Góra, Tatry, Kasprowy Wierch, Bałtyk, Wisła);

\footnotetext{
${ }^{75}$ Odezwa do Polaków w świecie, „Wychowanie Ojczyste”, III-IV 1959, nr 2, s. 1.

${ }^{76}$ Ibidem, s. 177.

77 S. Tync, J. Gołąbek, J. Duszyńska, op. cit., s. 99, 128.

${ }^{78}$ J. Otwinowska, op. cit., s. 177.
} 
- Ważne motywy (wierność żołnierska, nadzieja, odwaga, poświęcenie dla ojczyzny, patriotyzm);

- Literatura polska (Pan Tadeusz Adama Mickiewicza, Noc Listopadowa Stanisława Wyspiańskiego, Wierna rzeka Stefana Żeromskiego, Placówka Bolesława Prusa, poezje legionistów).

Jak widać, tematy i motywy podporządkowane były głównie historii Polski, jej geografii (z dużym naciskiem na Kresy), wierze, tradycjom, folklorowi polskiemu, czyli wszystkim aspektom implikujacym polskość i walkę o niepodległość. Tę kwestię najwyraźniej obrazuje ukazana w poniższym zestawieniu zmiana tekstu czytanki opowiadajacej o Święcie Niepodległości 11 listopada w podręczniku z okresu II wojny w porównaniu z podręcznikiem z dwudziestolecia międzywojennego.

Benedykt Kubski, Mieczysław Kotarbiński, Ewa Zarembina, Czytanka dla III klasy
miejskich szkót powszechnych/Czytanka dla III klasy szkót powszechnych

\begin{tabular}{|c|c|}
\hline wyd. Lwów 1934 & wyd. Jerozolima 1943 \\
\hline \multicolumn{2}{|c|}{$\begin{array}{l}\text { „Dziś jest rocznica oswobodzenia naszej ojczyzny od najazdu wrogów. Od dnia } 11 \text { listopada } 1918 \text { roku } \\
\text { Polska" } 9\end{array}$} \\
\hline ,jest wolna, jak dawniej”"80 & „była wolna”"1 \\
\hline $\begin{array}{l}\text { „- Polska jest bogata, - twierdzi Janina - bo ma } \\
\text { i koleje, i fabryki, i wojsko, i wszystko. } \\
\text { - Polska jest biedna, - mówi Jurek - bo ma za } \\
\text { mało szkół, za mało dróg, za mało szpitali. } \\
\text { - Żeby to można było podarować Polsce szpital } \\
\text { albo szkołę...”82 }\end{array}$ & $\begin{array}{l}\text { „- Teraz jest wojna - mówi Janina - i wszyscy } \\
\text { musimy pracować, aby się jak najprędzej skoń- } \\
\text { czyła. } \\
\text { - Żeby to każdy z nas mógł zabić choć jednego } \\
\text { Niemca - wzdycha Jurek. To byłby ładny poda- } \\
\text { runek dla Polski. [...] } \\
\text { - Na wojnę pójść jeszcze nie możecie - powiada } \\
\text { pani nauczycielka. Ale wszyscy możemy pomóc } \\
\text { do szybszego wygrania wojny"s3. }\end{array}$ \\
\hline
\end{tabular}

Źródło: opracowanie własne.

Święto jest dniem, w którym mówi się o niepodległości i docenia ja, ponieważ nadeszła lub dlatego że ponownie trzeba o nią walczyć.

Motyw walki niepodległościowej z okazji 11 listopada powraca w innym podręczniku, dla klasy IV, tyle że sposób jego ukazania łączy więcej symbolicznych wątków. W klimat święta wprowadza wiersz Edwarda Słońskiego, pt. W listopadowym stońcu:

79 B. Kubski, M. Kotarbiński, E. Zarembina, Czytanka dla III klasy miejskich szkót powszechnych..., s. 48; iidem, Czytanka dla III klasy szkót powszechnych..., s. 35.

${ }^{80}$ Iidem, Czytanka dla III klasy miejskich szkót powszechnych..., s. 48.

${ }^{81}$ Iidem, Czytanka dla III klasy szkót powszechnych..., s. 35.

${ }^{82}$ Iidem, Czytanka dla III klasy miejskich szkót powszechnych..., s. 48.

${ }^{83}$ Iidem, Czytanka dla III klasy szkót powszechnych..., s. 35. 
W listopadowym słońcu bawią się małe dzieci.

- Kiedyż ten Orzeł Biały naprawdę już przyleci?

[...]

Zagubił się w obłokach gdzieś na słonecznym szlaku...

- Czyż ty już nie przylecisz, królewski biały ptaku?

$[\ldots]$

To słyszał żołnierz polski, co szedł tą samą drogą

i po nierównym bruku drewnianą stukał nogą.

Snadź żal mu się zrobiło radości małych dzieci,

bo rzekł: - Nie wierzcie kupcom, nasz orzeł dziś przyleci ${ }^{84}$.

Następnie temat podejmuje tekst K. Konarskiego, który opisuje dzień 11 XI 1918 r. z perspektywy chłopca, mieszkańca Włocławka, uczestniczacego w rozbrajaniu niemieckich żołnierzy: „Miasto szalało. Tłumy, tłumy, tłumy. Przelewają się z ulicy w ulicę, przystaja, znów płyną. Ludzie krzycza, śmieją się, padaja sobie w objęcia. Płacza, a jasne, bo radosne łzy sypią się na uliczny bruk" ${ }^{85}$. Przedmiotem drugiej czytanki również jest patriotyzm młodych ludzi, ale z kolejnego pokolenia - 23 lata później. Oni także bardzo chca - mimo narażenia życia - podjać walkę z niemieckim okupantem i szukaja odpowiedniej metody okazania buntu. W rocznicę Święta Niepodległości 1941 r. „na murze jednej z kolumn na Cmentarzu Obrońców Lwowa jaśniał $\mathrm{w}$ ten listopadowy ranek wielki ZNAK POLSKI WALCZĄCEJ. Znak mówiący wrogom, że Polska choć w niewoli, żyje i walczy"s6.

Inny symbol narodowy posłużył do ukazania roli Święta Niepodległości w opowiadaniu opublikowanym na łamach czasopisma dla młodzieży „Na Harcerskim Szlaku"87. I tutaj rzecz dzieje się w czasie II wojny światowej, tyle że niedaleko Moskwy, na drodze do Smoleńska, w klasztorze oznaczonym tablica „Dom wypoczynkowy im. Maksyma Gorkiego”, a tak naprawdę w obozie jenieckim, w którym przetrzymywani byli polscy żołnierze: „Blade i nędzne twarze. Wielu z nich chodzi o kulach, wielu ręce na temblakach nosi, a nawet i puste nogawki i rękawy widać. Ubiór ich nędzny, lecz wiele zda się mówić swą jednolitą barwa. [...] Słońce przeglądało się w ich orzełkach na czapkach”88. 11 XI 1940 r. „Wszyscy czekali na "coś»”. Tym czymś były polskie pieśni, do których melodię wygrywał na starym fortepianie jeden z „łyczakowskich” więźniów. Pieśni nie były obce

tej ziemi. Czyż nie widziała ona już polskich żołnierzy? Tylko wtedy... wtedy oni byli zwycięzcami. Teraz - śpiewaliśmy my, raby, dzieci uciemiężonej Matki.

Obchodziliśmy święto 11 listopada. Bolszewicy dotąd nie rozumieli, chociaż bali się - widzieliśmy wyraźnie ich pomieszane twarze. Zrozumieli dopiero, gdy po kilku

\footnotetext{
${ }^{84}$ E. Słoński, W listopadowym słońcu, w: Czytanka na klase IV, Londyn 1979, s. 42.

${ }^{85}$ K. Konarski, 11 listopada 1918 roku, w: Czytanka na klase IV..., s. 45.

${ }^{86}$ B. Mękarska, Znak Polski Walczqcej, w: Czytanka na klase IV..., s. 130.

87 „Jerzy”, Święto 11 listopada, „Na Harcerskim Szlaku”, 2 X 1943, s. 2-3.

${ }^{88}$ Ibidem, s. 2.
} 
fałszywych akordach fortepianu - śpiewający wyprężyli zmęczone i wynędzniałe ciała, głowy z orzełkami wznieśli wyżej i nadchodzącym burzom zuchwałe rzucili wyzwanie: „Nie rzucim ziemi...”

Tak zakończyliśmy swoje Święto ${ }^{89}$.

Drugim świętem, które pojawiało się we wszystkich podręcznikach i materiałach dydaktycznych do edukacji dzieci polonijnych, był przywoływany już 3 Maja. Poświęcano mu wiersze. Maria Konopnicka pisała:

\section{Trzeci Maj}

$\mathrm{Na}$ warszawskim rynku,

Choragwie się chwieja,

Zajaśniała wiosna,

Majowa nadzieja!

$$
\text { [...] }
$$

O ty dniu radosny,

O ty Trzeci Maju,

Zapachniałeś kwieciem

W całym polskim kraju ${ }^{90}$.

Także Marian Czuchnowski opiewał to święto:
Dzień 3-go Maja
[...]
Święć się, święć się Trzeci Maju,
Święć się, święć się majowa jutrzenko,
Pukająca wesoło w okienko.
Budź głośno po kraju,
Niech naród, niech ludzie wstawają ${ }^{91}$.

Opisywano je w czytankach (np. Trzeciego maja $w$ miasteczku: „Bo dziś jest święto wszystkich, święto Ojczyzny. [...] Cieszę się, że młodzi są u nas weseli i zdrowi. Polska potrzebuje zdrowych i radosnych obywateli. Biało-czerwone choragiewki łopocza w słońcu. Orkiestra gra. To jest nasz trzeci maj”92) oraz tłumaczono jego znaczenie w krótkich wykładach, np. Trzeci Maj Świętem Polaków na całym Świecie. Majowa rocznica:

Święto Konstytucji stało się uroczystością szczerej solidarności narodowej, [...] manifestacjac dumy narodowej [...] Dla nas Polaków na Emigracji, wspomnienia samej Konstytucji i jej obchodów w Polsce Niepodległej mają sens specjalny i swoistą wymowę. Dzień ten jest świętem wszystkich Polaków, rozsianych po całym świecie. [...] wszystko co tradycja narodowa łączy z ta

89 Ibidem, s. 3.

${ }^{90}$ M. Konopnicka, Trzeci Maj, w: Czytanki na III poziom nauczania polskiego, Niezależny Związek Nauczycielstwa Polskiego we Francji, 1957, s. 89.

${ }^{91}$ M. Czuchnowski, Dzień 3-go Maja, w: J. Otwinowska, op. cit., s. 134.

${ }_{92}$ B. Kubski, M. Kotarbiński, E. Zarembina, Czytanka dla III klasy miejskich szkót powszechnych..., s. 108; iidem, Czytanka dla III klasy szkót powszechnych..., s. 88-89. 
epoką [tj. epoką uchwalenia Konstytucji - D.J.G.] da się ująć w dążeniach drogich wszystkim Polakom: wielkości Ojczyzny i wolności Jej obywateli ${ }^{93}$.

O tym, jak rzeczywiście ważne dla Polaków na emigracji było to święto, świadczą symboliczne odniesienia - choćby DARU NARODOWEGO 3 MAJA, o czym już wspominałam, ale także duże ilości poświęconych mu materiałów dydaktycznych wydawanych co roku np. na łamach „Wychowania Ojczystego". Pomoce dydaktyczne - opowiadania, wiersze, scenariusze lekcji historii i języka polskiego czy inscenizacji teatralnych - poprzedzano fachowymi, merytorycznymi wprowadzeniami przygotowanymi przez specjalistów, np. prof. Władysław Folkierski opracował artykuł Nieprzerwane życie ustawy majowej w narodzie ${ }^{94}$, dr Józefa Mękarska - Ziemie wschodnie Rzeczypospolitej za granica jattańsk ${ }^{95}$, mgr Michał Goławski - Idea wolności w Konstytucji 3 maja $^{96}$, a prof. dr Marian Kukiel napisał tekst Jutrzenka Majowa $i$ Jutrzenka Swobody, w którym przywołał najważniejsze przesłanie Konstytucji 3 maja:

Gdy co roku przed naszym narodowym świętem bierze się do ręki tę Ustawę Rządową 3 Maja 1791 by raz jeszcze przypomnieć sobie jej brzmienie, zastanowić nad treścia, od razu opanowuja myśl wstępne słowa, którymi król i stany skonfederowane naród polski reprezentujące wprowadzały ową konstytucję, istotnie wiekopomna: „Długim doświadczeniem poznawszy zadawnione rządu naszego wady, a chcąc korzystać z pory, w jakiej się Europa znajduje i z tej dogorywającej chwili, która nas samym sobie wróciła: wolni od hańbiącej obcej przemocy nakazów, ceniąc drożej nad życie, nad szczęśliwość osobista, egzystencję polityczna, niepodległość zewnętrzną i wolność wewnętrzną narodu, [...] dla dobra powszechnego, dla ugruntowania wolności, dla ocalenia ojczyzny naszej i jej granic, z największą stałością ducha niniejszą Konstytucję uchwalamy"97.

\section{Następnie konkludował:}

Dzisiaj, chociaż jest „Republica Polska” mieniąca się „Ludową”, nie lud polski tam włada. Choć suwerenną się mieni, nie jest wolnq od hańbiacych obcej przemocy rozkazów - czy zakazów. Nie jest władna kształtować samodzielnie swoich losów. Zaprzeczeniem idei przewodniej Ustawy majowej, idei rzqdnej wolności była przez dziesięcioletnie potwornej niewoli cała rzeczywistość polskiego życia, zdanego na pastwę bezprawia i najdzikszej samowoli zbrodniczych służalców obcej przemocy ${ }^{98}$.

${ }_{93}$ Czytanki na III poziom..., s. 88.

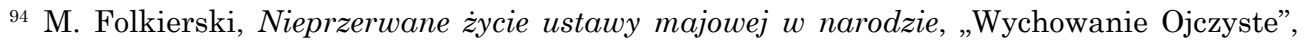
III-IV 1958, nr 2, s. 2-5.

95 J. Mękarska Ziemie wschodnie Rzeczypospolitej za granica jałtańska, „Wychowanie Ojczyste", I-II 1957, nr 8, s. 22-25.

${ }_{96}$ M. Goławski, Idea wolności w Konstytucji 3 maja, „Wychowanie Ojczyste”, I-II 1960, nr 1, s. 5-6.

${ }_{97}$ M. Kukiel, Jutrzenka Majowa i Jutrzenka Swobody, „Wychowanie Ojczyste”, III-IV 1957, nr 9, s. 2.

98 Ibidem, s. 3. 
„Oby ta jutrzenka swobody rozjaśniła dtugie narodowe noce, a $\dot{z}$ będziemy naprawdę wolni i razem powitamy w Warszawie majowa jutrzenkę święcąca znowu naszej polskiej krainie [podkreślenie D.J.G.]"99.

Było to merytoryczno-emocjonalne wprowadzenie do umieszczonego po tekście scenariusza lekcji historii dla uczniów poziomu wyższego (wiek 11-13 lat) na temat: Konstytucja 3 Maja 1791 roku. Cel lekcji brzmiał: „Uświadomienie w umyśle i sercu dzieci czym było i jest dla wszystkich Polaków święto 3 maja”, a do właściwego tematu nawiązywało stwierdzenie:

Każdy naród posiada w swej historii dni chwały i dni klęski. Pierwsze - wspomina i stara się je przekazać jako wzór swym następcom, obchodząc uroczyście jako święto całego narodu. Drugie - rozważa i analizuje aby tych błędów historycznych uniknąć w przyszłości. [...] Naszym największym świętem narodowym jest [...] uchwalenie Konstytucji 3 Maja - to znaczy dokonanej w r. 1791 reformy państwa ${ }^{100}$.

Po omówieniu najważniejszych uchwał i praw zawartych w Konstytucji pojawiała się konkluzja:

Konstytucja 3 Maja była wiekopomnym wydarzeniem w dziejach Polski, a na owe czasy była przykładem jak można dokonać reformy państwa bez rozlewu krwi i gwałtu. Dlatego to cały naród polski uznał dzień 3 Maja za święto narodowe. [...] Nic dziwnego, że Rosja nie chciała dopuścić do wprowadzenia Konstytucji 3 Maja w życie i już następnego roku wojska rosyjskie wkroczyły do Polski, aby przywrócić w Polsce taki stan bezładu i słabości wewnętrznej, jaki był przed uchwaleniem Konstytucji 3 Maja $^{101}$.

Materiały dydaktyczne uzupełniające treści historyczno-literackie to scenariusz inscenizacji z okazji 3 Maja oraz wiersze: Uparty Mazurek Antoniego Bogusławskiego, Trzeci Maj Marii Konopnickiej, Trzeci Maj Marii Krüger czy $W$ dniu trzeciego maja Czesława Janczarskiego ${ }^{102} \mathrm{z}$ dołączonymi nutami ułatwiającymi naukę śpiewu patriotycznych pieśni i piosenek. W innych numerach „Wychowania Ojczystego” znaleźć można cytowane już odezwy z okazji 3 Maja, materiały do przemówien ${ }^{103}$, obszerne fragmenty Konstytucji 3 maja, nierzadko opatrzone stosowną refleksja, np. „Po drugiej wojnie światowej ustrój narzucony Polsce przez Rosję Sowiecką usuną pamięć Konstytucji 3 Maja i dzień ten nie jest w Polsce oficjalnie uznawany za święto narodowe. Uznaje go natomiast w sercach swoich cały naród polski tak w Kraju jak i na emigracji”"104 czy też:

\footnotetext{
99 Ibidem, s. 4.

${ }^{100}$ Ibidem, s. 4-5.

${ }^{101}$ Ibidem, s. 6.

102 Ibidem, s. 18-20.

103 „Wychowanie Ojczyste”, I-II 1959, nr 1, s. 6-8.

104 „Wychowanie Ojczyste”, III-IV 1958, nr 2, s. 1.
} 
Nie wystarczy jednak obchodzić rocznicę świąt narodowych, przypominać je sobie i zaszczepiać w młodym pokoleniu poczucia patriotyzmu. [...] Trzeba uczyć i wychowywać dzieci po polsku w tradycjach narodowych i religijnych naszych ojców, dziadów i pradziadów.

To jest nasz obowiązek na dziś i na jutro, jeśli chcemy, aby emigracja polska, ta nowa po drugiej wojnie światowej, pozostała emigracja polską ${ }^{105}$.

Bardzo inspirujące są też autentyczne wypracowania młodzieży szkolnej na temat 3 Maja, przesłane do redakcji przez dyrektorów szkół, profesorów i młodzież polskich szkół średnich w Anglii.

Warto nadmienić $\mathrm{w}$ tym miejscu o działaniach młodzieży w powojennej Polsce w związku z 3 Maja. Przypomnijmy, że władze państwowe PRL zaniechały obchodów 3 Maja od 1946 r. na rzecz 22 Lipca dla upamiętnienia Manifestu Polskiego Komitetu Wyzwolenia Narodowego oraz 1 Maja jako święta mas pracujących. Szersze omówienie zagadnienia wymagałoby osobnego opracowania, przywołamy więc dla zobrazowania sytuacji parę dobitnych przykładów pochodzących z „Biuletynów Informacyjnych Ministerstwa Bezpieczeństwa Publicznego” z 1947 r.: „W Łodzi 3 Maja około godz. 11 na trybunę przy ul. Piotrkowskiej wszedł student wydziału stomatologicznego U[niwersytetu] Ł[ódzkiego] - członek PS, i wzywał wracających z kościoła studentów do demonstracji. Wyżej wymieniony został aresztowany, a nieliczna grupa studentów próbowała go odbić. Zostali oni natychmiast rozproszeni" ${ }^{106}$.

3 Maja w Białymstoku w 2 szkołach, w których wygłoszono referaty na temat: dlaczego dzień 3 Maja jest uczczony przez obywateli praca, uczennice próbowały demonstrować. W jednej szkole rozległy się tupania i gwizdy, tak że mówczyni była zmuszona przerwać. W drugiej zaś uczennice siedziały cicho w czasie referatu, a biły demonstracyjnie brawo, gdy jedna z uczennic zaczęła wygłaszać referat o konstytucji ${ }^{107}$.

W całym kraju 3 Maja przeszedł spokojnie. W Białymstoku i w Gliwicach jedynie miały miejsca $[\ldots]$ podane niżej wydarzenia:

3 Maja uczniowie liceów ogólnokształcącego, pedagogicznego i budowlanego w Białymstoku urządzili pochód, który udał się do kościoła Św. Wojciecha. Po wyjściu z kościoła młodzież przeszła zorganizowanie przez centrum miasta, niosąc sztandar szkolny [...].

W Gliwicach uczennice gimnazjum wraz z nauczycielką próbowały zorganizować demonstrację - zebrało się ponad 100 dziewczynek. Próba nie udała się.

W mieście Kałczyn nie ustaleni dotychczas sprawcy na kilkunastu afiszach z napisem Niech żyje 1 Maj nalepili na jedynkę trójkę 108.

${ }^{105}$ „Wychowanie Ojczyste”, I-II 1959, nr 1, s. 8.

${ }_{106} 3$ Maj. Biuletyn Informacyjny nr 6, w: Ministerstwo Spraw Wewnętrznych, Biuletyny Informacyjne Ministerstwa Bezpieczeństwa Publicznego 1947, t. I, red. B. Gronek, I. Marczak, Warszawa 1993, s. 71.

107 Ibidem.

${ }^{108} 3$ Maja. Biuletyn Informacyjny nr 4, w: Ministerstwo Spraw Wewnętrznych, op. cit., s. 53. 
Ostatnia z przywołanych sytuacji przypomina cytowany wcześniej opis wyczynu młodego mieszkańca Lwowa, który na murze kolumny na Cmentarzu Obrońców Lwowa namalował Znak Polski Walczącej „mówiący wrogom, że Polska choć w niewoli, żyje i walczy"109.

Znamienne jest też, że choć zacytowane fragmenty biuletynów Ministerstwa Bezpieczeństwa Publicznego deprecjonowały ten dzień jako święto narodowe (określenie to zresztą się nie pojawiło), to chyba podświadome przywiązanie jednak sprawiło, że zachowywano pisownię wielka litera. Pewnych tradycji nie można było tak łatwo wykorzenić.

Wracajac do materiałów dydaktycznych zawartych w przywoływanych wcześniej czasopismach dla nauczycieli przedmiotów ojczystych na obczyźnie, należy podkreślić, że dotyczyły one różnorodnych kwestii i przybierały różne postacie (artykuły, scenariusze, materiały literackie, dokumenty itp.). Jeden z bardzo rozbudowanych działów był poświęcony najwybitniejszym postaciom z polskiej historii: „Wybitni Polacy i ich działalność w walce o odzyskanie niepodległości”. W osobnych artykułach przedstawiono sylwetki i dokonania m.in. Jana Matejki ${ }^{110}$, Henryka Sienkiewicza ${ }^{111}$, Tadeusza Kościuszki ${ }^{112}$, Józefa Piłsudskiego ${ }^{113}$, Ignacego Jana Paderewskiego ${ }^{114}$, Ignacego Daszyńskiego ${ }^{115}$, Romana Dmowskiego ${ }^{116}$, Wincentego Witosa ${ }^{117}$.

Dokładniejsze omówienia i analizy postaci oraz wydarzeń historycznych znalazły swoje miejsce w podręcznikach do nauki historii, a także do nauczania języka polskiego w szkołach licealnych, ale to już materiał wymagajacy odrębnej analizy.

Linię ideowa wychowania patriotycznego w szkołach powszechnych na obczyźnie oddają dwa podręcznikowe hasła: Dlaczego kocham Polskę?118 oraz:

Nie wydrzecie!

[...] wy tego ukochania

109 B. Mękarska, Znak Polski Walczqcej..., s. 130.

110 J. Jastrzębiec, Jan Matejko, „Wychowanie Ojczyste”, XI-XII 1956, nr 7, s. 2-4.

111 M. Danilewiczowa, Henryk Sienkiewicz, „Wychowanie Ojczyste”, IX-X 1956, nr 6, s. 2-4.

112 M. Goławski, Tadeusz Kościuszko, „Wychowanie Ojczyste”, III-IV 1957, nr 9, s. 26-28.

${ }^{113}$ Idem, 1867 - Józef Pitsudski - 1933, „Wychowanie Ojczyste”, XI-XII 1958, nr 6.

114 Z. Kozarynowa, Ignacy Jan Paderewski (1860-1941), „Wychowanie Ojczyste”, I-II 1959, nr 1, s. 2-5.

${ }^{115}$ L. Ciołkoszowa, Ignacy Daszyński (1866-1936), „Wychowanie Ojczyste”, VII-VIII 1959, nr 4, s. 2-6.

116 T. Bielecki, Roman Dmowski (1864-1939), „Wychowanie Ojczyste”, V-VI 1959, nr 3, s. 2-6.

117 M. Thugutt, Wincenty Witos 1874-1945, „Wychowanie Ojczyste”, VII-VIII 1959, nr 4, s. 2-4. Ponadto do 1959 r. w przywołanym dziale ukazano sylwetki Józefa Conrada-Korzeniowskiego, Ewarysta Estkowskiego, Stanisława Jachowicza, ks. Stanisława Konarskiego, Marii Konopnickiej, Józefa Ignacego Kraszewskiego, Stanisława Moniuszki, Heleny Orszy-Radlińskiej, Elizy Orzeszkowej, Bolesława Prusa, Marii Skłodowskiej-Curie, Stanisława Wyspiańskiego.

${ }^{118}$ Czytanki na III poziom..., s. 121. 
Nawet z życiem nie wydrzecie.

Nie wydrzecie z serc i dłoni,

Jak ta ziemia wszerz i długa.

Póki jeden pacierz dzwoni,

Póki jeden chłop u pługa!

Póki jedna polska matka!

Póki jedno polskie dziecię!

Bronić będziem do ostatka!

Nie wydrzecie, nie wydrzecie!

(Kazimierz Laskowski) $^{119}$.

\section{Streszczenie}

Druga Wielka Emigracja w Wielkiej Brytanii po 1945 r. postawiła sobie za cel patriotyczną edukację młodego pokolenia w ramach kształcenia i utrzymania tożsamości narodowej. Zadania te wpisały jako wytyczne swej działalności Wydział Oświaty i Wychowania oraz współpracujące z nim instytucje i stowarzyszenia. Potrzebę tę artykułowali politycy (m.in. gen. Władysław Anders), a realizowali zgodnie z hasłami programowymi zawartymi w podręcznikach i materiałach dydaktycznych nauczyciele Szkół Przedmiotów Ojczystych. Początek edukacji emigracyjnej wymagał zorganizowania całego funkcjonalnego systemu i wydania podręczników, począwszy od Elementarza, a skończywszy na książkach dla starszych uczniów, które w pierwszych latach były przedrukami podręczników z lat międzywojnia, a później m.in. owocem ofiarności społeczeństwa polskiego na emigracji w ramach „Daru Narodowego 3 Maja”. Dodatkowe obciążenie stanowił fakt, że emigracyjne materiały dydaktyczne miały nie tylko realizować cele poznawcze, ale przede wszystkim ukazywać prawdę historyczną i polityczną fałszowaną w edukacji PRL-u, która nastawiona była na gloryfikowanie ustroju socjalistycznego i przyjaźni ze Związkiem Sowieckim (co widać już w nowej wersji Elementarza Mariana Falskiego). Dobór treści w podręcznikach polonijnych podporządkowany został założonym celom edukacyjnym, z czego wynikała dominacja określonych pól tematycznych, m.in. sławni Polacy, ważne miejsca i wydarzenia historyczne, symbole narodowe, tradycje, zwyczaje, motywy, święta - zwłaszcza nieuznawane przez rząd socjalistyczny - 3 Maja i 11 listopada. Poświęcone im były teksty poetyckie i prozatorskie w podręcznikach do kształcenia polonistycznego oraz materiały dydaktyczne w czasopismach dla harcerzy i nauczycieli, np. scenariusze lekcji, inscenizacje, artykuły, dokumenty, wybór tekstów poetyckich, piosenek, nut itp.

\section{Patriotism in the Educational Activities of the Polish Independence Emigration on the Example of Great Britain in 1945-1990}

The Second Great Emigration in Great Britain after 1945 set themselves the goal of patriotic education of the young generation as part of shaping and maintaining national identity. These tasks were included as guidelines both of the Department of Education and Upbringing, and institutions and associations cooperating with it. This need was articulated by politicians (including General Władysław Anders), and was fulfilled in accordance with the programme slogans of textbooks and didactic materials by the teachers of the Polish Schools of Native Subjects (also called Polish schools). The beginning of emigrant education required

119 Ibidem. 
to organise the entire functional school system and textbooks, from the primer to textbooks for older students, which in the first years were reprints of interwar textbooks, and later were, among others, the fruit of the generosity of the Polish society in exile as part of the "3 May National Gift". An additional burden was that the emigrant didactic materials were not only to accomplish learning objectives, but above all to present the historical and political truth falsified by the education system of the Polish People's Republic, which was aimed at glorifying the socialist system and friendship with the Soviet Union (which could already be seen in the new version of Marian Falski's primer). The choice of content in the textbooks of Polish communities abroad was subordinated to specific educational goals which resulted in the domination of certain thematic areas, such as famous Poles, important places and historical events, national symbols, traditions, customs, traditional Polish motifs, holidays especially those not recognized by the socialist government: 3 May and 11 November. There were poetic and prose narratives devoted to them in textbooks for Polish-language education and didactic materials in periodicals for scouts and teachers, e.g. lesson plans, performances, articles, documents, selection of poetic texts, songs, notes, etc.

\section{Bibliografia}

Bober-Pełzowska M., Tuzimek J., Nauka czytania i pisania w elementarzach Mariana Falskiego, w: Problemy psychodydaktyki nauczania poczatkowego, red. M. Przetacznik-Gierowska, Warszawa 1992, s. 10-65.

Bogusławska A., Czy potrzebny jest nowy Elementarz?, „Wychowanie Ojczyste”, III-IV 1956, nr 3, s. 1-7.

Brańska E., Zapomniany autor Elementarza, „Wychowanie w Przedszkolu” 2005, nr 10, s. 13-17.

Chwastyk-Kowalczyk J., Polskie czasopisma emigracyjne wspierajace edukacje $w$ Wielkiej Brytanii w latach 1946-2017, „Przegląd Historyczno-Oświatowy” 2017, nr 1-2, s. 133-153.

Dąbrowski J., Z rozważań o wychowaniu, „Wiadomości Nauczycielskie”, I-III 1946, nr 7-9, s. $2-5$.

Gliński M., Marian Falski, autor kultowego „Elementarza” urodzit się 130 lat temu, culture.pl, https://culture.pl/pl/artykul/marian-falski-autor-kultowego-elementarza-urodzil-sie130-lat-temu (dostęp: 20 X 2018).

Jurek A., W czym tkwi fenomen Elementarza Falskiego, http://www.reedukacja.pl/default.aspx? action=view\&item=586 (dostęp: 2 X 2018).

Kondracki T., Historia Stowarzyszenia Polskich Kombatantów w Wielkiej Brytanii 1946-1996, Londyn 1996.

Ludzińska K., Szkolnictwo polskie w Wielkiej Brytanii, „Studia Polonijne” (Lublin) 1983, t. VII, s. $127-150$.

Paryż - Londyn - Monachium - Nowy Jork. Powrześniowa emigracja niepodległościowa na mapie kultury nie tylko polskiej, t. II, red. V. Wejs-Milewska, E. Rogalewska, Białystok 2016.

Pędrak A., Szkolnictwo polonijne w Wielkiej Brytanii i Irlandii, 2017, http://dx.doi.org/ 10.18778/8088-705-3.02 (dostęp: 18 IX 2018).

Radzik T., Historia Zrzeszenia Nauczycielstwa Polskiego za Granica 1941-1991, Londyn 1999.

Radzik T., Polska diaspora w Wielkiej Brytanii, w: Polska diaspora, red. nauk. A. Walaszek, Kraków 2001, s. 149-166.

Radzik T., Szkolnictwo polskie w Wielkiej Brytanii po drugiej wojnie światowej, Lublin 1991.

Radzik T., $Z$ dziejów społeczności polskiej w Wielkiej Brytanii po drugiej wojnie światowej (1945-1990), Lublin 1991.

Szczepański J.A., To byt elementarz!, Nowiny24, https://nowiny24.pl/to-byl-elementarz/ar/ 5921087 (dostęp: 12 X 2018). 
Zamecka-Zalas O., Pedagodzy - zastużeni dla zachowania tożsamości narodowej Polaków na uchodźstwie po II wojnie światowej (na przykładzie organizacji Polska Macierz Szkolna), w: Dom rodzinny w doświadczeniu (auto)biograficznym, red. A. Ładyżyński, M. Piotrowska, M. Kasprzak, Wrocław 2017, s. 201-216.

Biog r a m: Danuta Jastrzębska-Golonka - dr hab. nauk humanistycznych w zakresie językoznawstwa, prof. nadzw.; kierownik Zakładu Dydaktyki Literatury i Języka Polskiego Uniwersytetu Kazimierza Wielkiego w Bydgoszczy. Opublikowała szereg artykułów z zakresu m.in. językoznawstwa stosowanego, historii dydaktyki polskiej, dydaktyki literatury, języka polskiego i historii, problematyki nauczania i funkcjonowania dzieci niepełnosprawnych, języka młodzieży szkolnej, literatury dla dzieci i młodzieży. E-mail: jastrzebska-golonka@wp.pl. 